\title{
Side \\ An emerging threat of Phytophthora infestans causing late blight of tomato in Uttar Pradesh, India
}

A.N. Tripathi*, K.K. Pandey, B.R. Meena, A.B. Rai and B. Singh

Division of Crop Protection, ICAR - Indian Institute of Vegetable Research, Varanasi, Uttar Pradesh - 221305, India

*E-mail: antripathi_patho@rediffmail.com

Received: 17 Jan 2017. Published: 06 Mar 2017. Keywords: disease incidence, Solanum lycopersicum, sporangia,

Tomato (Solanum lycopersicum) cultivation in India has expanded to 0.91 million ha in 2015-2016. Farmers originally cultivated this crop for selfconsumption but now are adopting it as a cash crop for commercial production. Recently, the occurrence of late blight on tomato, caused by Phytophthora infestans, in Uttar Pradesh, India has appeared to increase but average late blight incidence on tomato has not been well documented for this region. In early 2016, a severe outbreak of late blight was observed in tomato with a disease incidence up to $60 \%$ in farmers' fields in eastern Uttar Pradesh and at the IIVR Research Farm in Varanasi, also in eastern Uttar Pradesh. Initial disease symptoms appeared on leaves as irregular, water-soaked and light-brown lesions usually covered with white, cottony mycelial growth on the underside of the leaf (Fig. 1). Water-soaked brown lesions expanded rapidly on stem and green fruits. Infected green fruits often developed olivaceous, brown-coloured, leathery, hard structures (Fig. 2). All infected fruits eventually fell off the plants and could not be marketed or used for human consumption.

Isolation of the causal agent was done by a modified method described by Tumwine et al. (2000). Infected tomato leaves were collected and surface sterilised for 30 seconds in $90 \%$ ethanol. A $25-\mathrm{mm}^{2}$ section was cut from a leading edge of a lesion on the sterilised leaf. The sections were aseptically transferred to 5-mm-thick potato slices which had been sterilised with $96 \%$ ethanol for one minute and placed in 90-mm-diameter sterilised glass Petri plates. After incubation at $18 \pm 1^{\circ} \mathrm{C}$ for five days, colonisation by the pathogen was observed in the form of white mycelial growth (Fig. 3). Microscopic studies of the colonised pathogen on potato slices revealed hyaline, coenocytic, branched hyphae and aseptate sporangiophores with lemon-shaped, papillate sporangia. Sporangia $(n=100)$ dimensions were 32 $\pm 6.3 \times 20 \pm 4.9 \mu \mathrm{m}$, with a length to width ratio of 1.6 . On the basis of morphological characteristics and sporangia size, the pathogen was confirmed as P. infestans (Drenth \& Sendall, 2001).

To fulfill Koch's postulates, 5-mm sections from seven-day-old colonised potato slices were placed on detached leaves from 3-week-old tomato plants (variety 'Kashi Aman'). Control leaves were inoculated with sterile potato sections. Inoculated tomato leaves developed water-soaked lesions similar to those originally observed in the field within two days incubated at $18 \pm 1^{\circ} \mathrm{C}$. Phytophthora infestans was re-isolated from the infected detached leaves of tomato and identified morphologically. Control leaves did not develop symptoms and the pathogen was not recovered.

This report highlights the emergence of this pathogen in eastern Uttar Pradesh. The occurrence and impact of late blight in potato is well documented. Regional and seasonal incidence of late blight on potato showed highest average annual crop losses in South-East Asia (35\%), including India (40-75\%) and Bangladesh (25-57\%) (International Potato Center, 1997; Rahman et al., 2008; Arora, 2015). Phytophthora infestans is one of the most important pathogens on solanaceous vegetables worldwide threatening food security (Fisher et al., 2012). Its management is dependent on chemical control but pathogen resistance is known to occur. Therefore, there is an urgent need to develop resistant varieties of tomato for changing climatic scenarios.

\section{Acknowledgements}

The authors acknowledge the research facilities provided by the Director, ICAR- Indian Institute of Vegetable Research, Varanasi, Uttar Pradesh.

\section{References}

Arora RK, 2015. Strategic management for Irish potato famine fungus. Indian Horticulture 60, 44-47.

Drenth A, Sendall B, 2001. Practical guide to detection and identification of Phytophthora. CRC for Tropical Plant Protection Brisbane. Version 1.0, 20-27.

International Potato Center (CIP), 1997. Annual Report. The International Potato Centre, Lima Peru, 179.

Fisher MC, Henk DA, Briggs CJ, Brownstein JS, Madoff LC, McCraw SL, Gurr SJ, 2012. Emerging fungal threats to animal, plant and ecosystem health. Nature 484, 186-194. http://dx.doi.org/10.1038/nature10947

Rahman MM, Dey TK, Ali MA, Khalequzzaman KM, Hussain MA, 2008. Control of late blight disease of potato by using new fungicides. International Journal of Sustainable Crop Production 3, 10-15. http://dx.doi.org/10.1016/S0269-915X(00)80096-8

Tumwine J, Frinking HD, Jeger MJ, 2000. Isolation techniques and cultural media for Phytophthora infestans from tomato. Mycologist 14, 137-139. http://dx.doi.org/10.1016/S0269-915X(00)80096-8

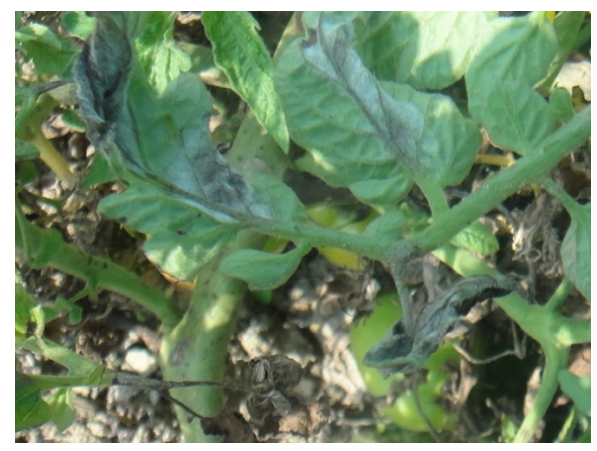

Figure 1

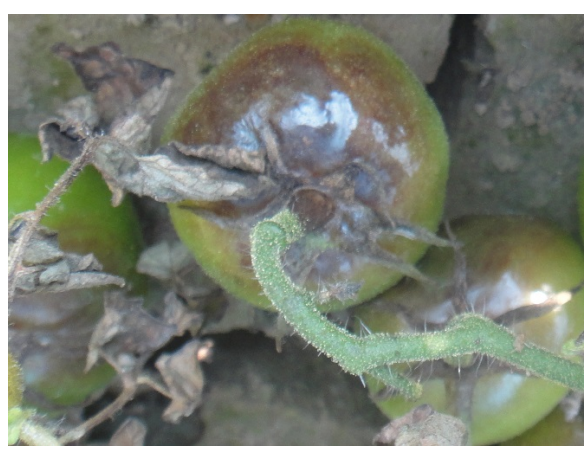

Figure 2

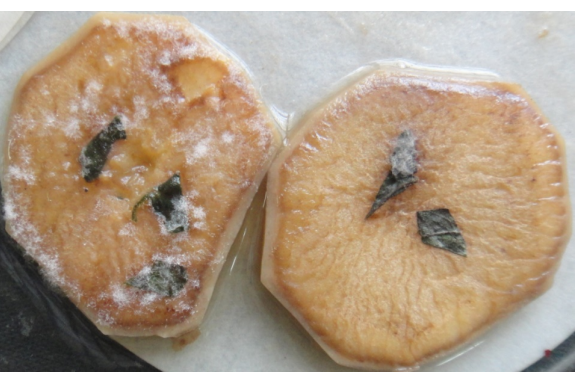

Figure 3

To cite this report: Tripathi AN, Pandey KK, Meena BR, Rai AB, Singh B, 2017. An emerging threat of Phytophthora infestans causing late blight of tomato in Uttar Pradesh, India. New Disease Reports 35, 14. http://dx.doi.org/10.5197/j.2044-0588.2017.035.014 